\title{
Does External Supervision Reduce the Risk Preference on Shadow Banking? (Note 1)__Evidence from Quasi-Natural Experiment Based on "Document No.107" of the State Council and National Audit Notice
}

\author{
Jiahua Wang ${ }^{1}$, Yuanfang Cao ${ }^{1}$, Xiaoling Yang ${ }^{1} \&$ Yue Wang $^{2}$ \\ ${ }^{1}$ School of Finance, Nanjing Audit University, Nanjing, China \\ ${ }^{2}$ College of Economics and Management, Nanjing University of Aeronautics and Astronautics, Nanjing, China \\ Correspondence: Jiahua Wang, School of Finance, Nanjing Audit University, Nanjing, China. Tel: \\ 138-5183-7107. E-mail: jiahua777@vip.sina.com
}

Received: May 6, 2018

doi:10.5539/ijef.v10n7p108
Accepted: June 11, 2018

Online Published: June 15, 2018

URL: https://doi.org/10.5539/ijef.v10n7p108

\begin{abstract}
The rapid development of shadow banking and its high-risk problems have got highly concerned from the supervision departments, and they have been supervised from various external aspects. The purpose of this study is to examine whether the administrative supervision can reduce the risk preference of shadow banking effectively from two aspects such as the "Document No.107" of the State Council and national audit. This study quantifies the effect of "Document No. 107" and national audit by the non-observed-effect panel data model and the PSM-DID. The results show that "Document No.107" and national audit can regulate shadow banking significantly by controlling other factors, which is reflected by the fact that the decreasing of shadow banking's scale and the improvement in risk structure can significantly reduce the risk preference of shadow banking. Since administrative supervision and national audit have different supervisory means and functional mechanisms, the cooperation and complementation between them must be necessary in the future during the regulation of shadow banking. Finally, this paper puts forward corresponding policy recommendations based on financial stability objectives.
\end{abstract}

Keywords: shadow banking, external supervision, risk preference, PSM-DID

\section{Introduction}

Financial institutions in China's financial market have been showing barbaric development since the start of shadow banking in 2010 . The current shadow banking system has taken up nearly $80 \%$ of China's economy and become a pivotal part of China's financial system. However, it is worth noting that the implied financial risks keep gathering and may even trigger systemic financial risks due to maturity mismatches, liquidity conversions, credit conversions, and high leverage while shadow banking is developing rapidly (Note 2). In order to control the risks of shadow banking, State Council of the PRC promulgated the "Notice of the General Office of the State Council on Strengthening the Issues Related to the Supervision of Shadow Banking ([2013]Document No. 107 of State Council)" (hereinafter referred to as "Document No.107") in December 2013. Later, it issued a series of regulatory policies."Document No.107" is a programmatic policy document for the administrative supervision of shadow banking. The core of the document is to prevent shadow banking risks by establishing financial supervision mechanism and urging related institutions to establish internal control system, risk disposal system and risk isolation mechanism. As one of the "eight major supervisions", national audit can quickly investigate violations in the financial sector and correct the risk preferences of financial institutions by audit notice and other methods. On the one hand, it has efficiency of corporate governance, and on the other hand, the professionalism and comprehensiveness of national audit are conducive to the comprehensive management of cross financial risks and to prevent systemic financial risks.

"Document No. 107" has been promulgated for 4 years, and the national audit has started its audit notice on central enterprises since the year of 2010. However, the existing studies have not examined the impacts of administrative supervision represented by "Document No.107" and national audit supervision represented by 
audit notice on the risk preference of shadow banking. And they both lack empirical tests on their roles in controlling bank's high-risk businesses. Therefore, whether administrative supervision and national audit can effectively restrict the risk preference on shadow banking in China and whether they can effectively prevent and control risks of shadow banking remain an important and urgent question to be answered.

\section{Theoretical Analysis and Research Hypothesis}

The high risks in financial field have caused academics and government supervisory authorities to pay close attention to the potentially large loopholes in the shadow banking system. Therefore, how to prevent and control the risks of shadow banking has become an important theoretical and practical issue. The premise of risk management is to conduct in-depth analysis of the root causes of risks. Many scholars believe that regulatory arbitrage is an important factor to cause shadow banking (Pozsar, 2013). However, unlike the foreign shadow banking pattern where asset securitization is dominant, indirect financing plays a main role in China's capital market. Under this financial pattern, shadow banking is mainly an innovation within the banking system and partially replaces the indirect financing function of commercial banks. Due to the inherent flaws of commercial banks, the emergence of shadow banking is just the result of market selection (Ryoo, 2010; Ba Susong, 2013; Chao et al., 2014).

As a product of financial innovation, scholars believe that shadow banking has low transparency and high leverage, and its rapid development accelerates the accumulation and transmission of financial risks (Gennaioli, 2012; Liu, 2014; Adrian, 2014). Due to the complexity of shadow banking risks, identification and measurement has become the basis of risk monitoring. Traditional shadow banking risk measurement models include GARCH model, matrix model and network model. After the financial crisis, new methods for measuring shadow banking risks have been developed, such as stress testing method and Monte Carlo simulation method (Nicolo, 2002; Huang, 2009; Lehar, 2005; Rui, 2013; Gertler, 2013). He Jing (2016) measured the evolutionary rules of shadow banking risks of financial institutions from the perspective of marginal risk contribution and discovered unique risks in China's special financial and economic environment. Some scholars have measured shadow banking risks from the aspects of the stability of the banking system, regional financial stability, and monetary policy transmission (Bo \& Ge, 2011; Zhou, 2013), and they proposed the basic framework for preventing shadow banking risks from the perspective of counter-cyclical policy, from trends of macroeconomy and finance, and the regional differential supervision (Zesheng, 2012; Xihe et al., 2014; Qing et al., 2016).

However, it is worth noting that when the academics have a high degree of consensus on shadow banking risks, few studies have empirically evaluated the actual effects of regulatory policies. It is difficult to tell whether the changes of shadow banking activities are caused by the policy effect of "Document No. 107" or the effect of national audit. Or, it is caused by other factors (such as bank asset security and profitability). That is to say, the existing literature, if any, just certified the correlation between these two regulatory approaches and shadow banking risks. No causal relationship has been inferred. Therefore, it is necessary to identify the respective net effect of administrative supervision and national audit from the empirical perspective.

For this reason, the focus of this paper is to examine whether the implementation of "Document No.107" and national audit can reduce the risk preference of the shadow banking activities of commercial banks separately. It is generally believed that different regulatory authorities will publish corresponding regulations to make social external constraints on regulatory objects and to the steady development of finance (Minkang et al., 2015). The shadow banking risks can be measured from two dimensions: the shadow banking scale and the shadow banking structure. However, with the further development of banking business innovation, the category of shadow banking is also expanding. In order to cover the scope of shadow banking as much as possible and considering the availability of data, this study uses the non-credit assets of China's Commercial Banks as a proxy variable of shadow banking.

The first one is the scale of shadow banking. Compared with shadow banking, the credit operation of commercial banks has safety precautions such as mortgages and guarantees, and its risks are more controllable. Therefore, it is reasonable to examine the bank's risk exposure from the allocation of credit assets. This study believes that if "Document No. 107" and national audit can effectively reduce the risks of shadow banking, the proportion of credit assets in the asset structure of commercial banks should be increased, and the scale of shadow banking should be decreased. Hypothesis 1, hypothesis 2 and hypothesis 3 are proposed for this purpose.

H1: By controlling other factors, "Document No. 107" can lead to a relative increase in the scale of bank credit operation.

H2: By controlling other factors, "Document No. 107" can lead to a relative decrease in the scale of shadow banking. 
H3: By controlling other factors, national audit can lead to a relative decrease in the scale of shadow banking.

The second one is the structure of shadow banking. At present, regulations on commercial banks still focus on two traditional areas - capital adequacy ratio and liquidity. However, for commercial banks, these regulations just give them chances to "innovate" and avoid supervision (Hongxing et al., 2016; Jiahua et al., 2017), leading to a wide variety of non-credit operations of commercial banks. Some of the operations aim to evade supervision (such as the conversion of multi-monitored loan operations into relatively less-regulated receivable investments, hold for trading financial assets and derivative financial instruments etc.), and some of them are meant to improve liquidity (such as due to banks and interbank lending, etc.). However, there are certain differences between the risk levels of different types of shadow banking. Obviously, the main purpose of the first type of shadow banking is to complete the internal conversion of credit assets within the balance sheet and convert it into other assets that are less regulated or even unregulated. This type of shadow banking increases the risks of financial system and reduces the anti-risk capacity of banks. It has a high-risk weight. The second type is the asset allocation within the commercial bank system. Although it is less regulated, it has a low level of risk. Therefore, if more assets are allocated to the first type of shadow banking, banks will have a higher risk preference. And if "Document No.107 " and national audit can effectively control the risks of shadow banking, the proportion of the second type of business will be increased, while the proportion of the first type will be decreased. Hypothesis 4 and Hypothesis 5 are proposed accordingly.

H4: By controlling other factors, "Document No. 107" can lead to a decrease in the proportion of high-risk weighted shadow banking activities.

H5: By controlling other factors, national audit can lead to a decrease in the proportion of high-risk weighted shadow banking activities.

\section{Research Design}

\subsection{Panel Data Model and Variable Definition}

This paper mainly discusses the influence of China's administrative supervision represented by "Document No.107" and national audit supervision based on audit notice on the risk preference of shadow banking of China's commercial banks. For this purpose, panel data regression method is adopted for independent empirical verification. Binary dummy variables representing "Document No.107" and national audit and a set of observable control variables of shadow banking that change over time are adopted as core explanatory variables. This paper manually reviewed the panel data of relevant observations of China's 24 banks from 2010 to 2016 (Note 3), including five large national commercial banks, eight joint-stock banks, nine city commercial banks and two rural commercial banks. Considering the lack of relevant data, some incomplete data are excluded from this study. The specific models that describe the impact of "Document No.107" and national audit on the risk preference of shadow banking are constructed as follows:

$$
\begin{aligned}
& \text { Struc }_{i t}=\beta_{0}+\alpha \text { Struc }_{i t-1}+\beta_{1} \text { Superv }_{i t}+\delta X_{i t}+C_{t}+C_{i}+\varepsilon_{i t} \\
& \text { Struc }_{i t}=\beta_{0}+\alpha \text { Struc }_{i t-1}+\beta_{2} \text { Audit }_{i t}+\delta X_{i t}+C_{t}+C_{i}+\theta_{i t}
\end{aligned}
$$

"il" represents the bank $(\mathrm{i}=1,2, \ldots, 24)$ and " $\mathrm{t}$ " represents time. "Struc $\mathrm{i}_{\mathrm{it}}$ " measures the business structure of bank $\mathrm{i}$ at time t. According to the above hypothesises, business structure refers to the proportion of bank credit assets $\left(\mathrm{Cred}_{\mathrm{it}}\right)$, the proportion of shadow banking activities (Shadow), the proportion of high-risk weighted shadow banking activities (H-Risk) and low-risk weighted shadow banking activities (L- Risk). There may be dynamic continuity in the banking business structure, so Struc $\mathrm{it}_{\mathrm{it}-1}$ is added to the model, which means, the current business structure may be highly related to the business structure of the previous period. "Superv" is a binary dummy variable. If bank $i$ is supervised by "Document No. 107" at time t, then $\operatorname{Superv}_{\mathrm{it}}=1$, otherwise $\operatorname{Superv}_{\mathrm{it}}=0$. "Audit" is also a binary dummy variable. If bank $i$ is audited by the National Audit Office at time $t$, it will take 1; otherwise, it will take 0 . " $\mathrm{X}_{\mathrm{it}}$ " is another factor that affects the banking business structure. Since banks are most concerned about how to reduce non-performing loans and improve profitability, this paper uses four indicators: non-performing loan ratio, loan provisioning rate, capital adequacy ratio and rate of return on common stockholders' equity in the matrix $X_{\mathrm{it}}$. These indicators are introduced in the form of control variables. " $\varepsilon_{\mathrm{it}}, \theta_{\mathrm{it}}$ " are random errors. " $\beta_{0}, \beta_{0}{ }^{\prime}, \beta_{1}, \beta_{2}$ "are parameters to be estimated. According to the purpose of this study, $\beta_{1}, \beta_{2}$ respectively measures the impacts of "Document 107" and national audit on the banking business structure, therefore they are the key parameters of this paper. $\delta$ measures the influence of the control variable matrix $\mathrm{X}_{\mathrm{it}}$ on the banking business structure. $C_{t}$ is the year fixed effect and $C_{i}$ represents non-observed effect. The variable definitions are listed in Table 1. 
Table 1. Variable definitions

\begin{tabular}{|c|c|c|}
\hline Variable name & Variable code & Variable definitions \\
\hline Banking structure & Struc & $\begin{array}{l}\text { The proportion of different banking businesses, which consists of four } \\
\text { indicators: the proportion of bank credit assets, the proportion of shadow } \\
\text { banking activities, the proportion of high-risk weighted shadow banking } \\
\text { activities and low-risk weighted shadow banking activities. }\end{array}$ \\
\hline The proportion of bank credit assets & Credit & Bank credit assets/total assets \\
\hline $\begin{array}{l}\text { The proportion of shadow banking } \\
\text { activities }\end{array}$ & Shadow & Shadow banking activities /total assets \\
\hline $\begin{array}{l}\text { The proportion of high-risk weighted } \\
\text { shadow banking activities }\end{array}$ & H-Risk & High-risk weighted shadow banking activities/total shadow banking activities \\
\hline $\begin{array}{l}\text { The proportion of low-risk weighted } \\
\text { shadow banking activities }\end{array}$ & L-Risk & Low-risk weighted shadow banking activities/total shadow banking activities \\
\hline Supervision of "Document No.107" & Superv & Binary dummy variable. Take 0 before the end of 2013 . Otherwise, take 1 . \\
\hline National Audit Supervision & Audit & $\begin{array}{l}\text { Binary dummy variable. Take } 1 \text { if audited by the National Audit Office. } \\
\text { Otherwise, take } 0 \text {. }\end{array}$ \\
\hline Non-performing loan ratio & NPL & Non-performing loans / loan balance \\
\hline Loan provisioning rate & ALR & Loan Loss Provisions Balance / Loan Balance \\
\hline Capital adequacy ratio & CAP & Regulatory capital/risk-weighted assets \\
\hline $\begin{array}{l}\text { Rate of return on common stockholders' } \\
\text { equity }\end{array}$ & ROE & Net profit/average shareholder's equity \\
\hline
\end{tabular}

\subsection{DID Model Based on "Quasi-Natural Experiment" to Control Endogeneity}

The difference-in-differences (DID) model was proposed by Ashenfelter and Card (1985), aiming to solve the problem of variable endogeneity. Due to the exogeneity of policy shocks and differences in influence area, policy-affected samples (Treated group, Treated) and unaffected samples (Experimental group, Exper) vary with the development of policies. Therefore, the DID model can compare the changes before and after the policy implementation to control the systemic differences between these two groups, which is conducive to identifying the net effect of "Document No.107" and national audit.

As an approach of administrative supervision, "Document No. 107" which was implemented in December 2013 has externalities. Therefore, the sample banks after December 2013 should be treated as a treated group (Treated), and the others before that time should be classified into an experimental group (Exper). Then, a difference-in-differences model is establised upon "Document No.107".

$$
\text { Struc }_{i t}=\lambda+\theta_{1} \text { Treated }_{i}+\theta_{2} \text { Exper }_{i}+\theta_{3} \text { Treated }_{i} * \text { Exper }_{i}+\delta X_{i t}+C_{t}+C_{i}+\varepsilon_{i t}
$$

The meanings of "Struc $\mathrm{it}_{\mathrm{it}}, \mathrm{X}_{\mathrm{it}}, \mathrm{C}_{\mathrm{t}}, \mathrm{C}_{\mathrm{i}}$ and $\varepsilon_{\mathrm{it}}$ "are consistent with formula (1). "Treated $\mathrm{i}_{\mathrm{i}}$ "is the dummy variable of the treated group while "Exper ${ }_{i}$ "is that of the experimental group. After December 2013, Treated $_{i}=1$. Otherwise, Treated $_{\mathrm{i}}=0$. The same goes with Exper $_{\mathrm{i}} \theta_{3}$ is a crossover variable that should be emphasized.

Similarly, audit notices from 2010 to 2016 were selected. Banks audited by the audit agency should be treated as the treated group (Treated), and other unaudited banks are classified into the experimental group (Exper). Then, a difference-in-differences model is established based upon National Audit.

$$
\text { Struc }_{i t}=\lambda^{\prime}+\theta_{1} \text { Treated }_{i}+\theta_{2} \text { Exper }_{i}+\theta_{3} \text { Treated }_{i} * \text { Exper }_{i}+\delta X_{i t}+C_{t}+C_{i}+\theta_{i t}
$$

The meanings of relevant variables in formula (4) are consistent with formula (2). "Treated ${ }_{i}$ " is the dummy variable of the treated group. If the bank has been audited by the audit agency, $\operatorname{Treated}_{i}=1$. Otherwise, Treated $_{i}$ $=0 . \theta_{3}{ }^{\prime}$ is a crossover variable that should be emphasized.

\section{Empirical Results and Analysis}

\subsection{The Panel Data Model}

\subsubsection{Descriptive Statistics}

Table 2 shows the descriptive statistics results of relevant variables in the panel data model. The mean of Credit is $48.772 \%$, and the median is $49.726 \%$. This indicates that with the development of financial innovation, the proportion of credit assets in commercial banks has generally declined, and the credit operations have become less important. In contrast, although shadow banking has a short history of development, the mean of Shadow 
has reached $35.869 \%$, and shadow banking activities has accounted for $67.825 \%$ of total assets, which fully indicates that shadow banking has great significance for commercial banks. Resources have been heavily invested into shadow banking. From the perspective of business structure, high-risk shadow banking activities take up an absolute proportion. The mean of H-Risk is $80.870 \%$, and the highest even reaches $96.638 \%$. This shows that among the sample banks, the risk accumulation caused by shadow banking has become a serious problem.

Table 2. Descriptive statistics

\begin{tabular}{ccccccccc}
\hline variable & Mean & median & Standard deviation & Minimum & 25th quantile & 75th quantile & Maximum & Number of observations \\
\hline Credit & 48.772 & 49.726 & 7.017 & 30.155 & 45.148 & 53.758 & 63.492 & 173 \\
Shadow & 35.869 & 34.001 & 10.063 & 10.291 & 29.126 & 40.298 & 67.825 & 166 \\
H-Risk & 80.870 & 82.843 & 10.516 & 48.976 & 75.498 & 88.588 & 96.638 & 122 \\
L-Risk & 19.130 & 17.175 & 10.516 & 3.362 & 11.412 & 24.502 & 51.024 & 122 \\
Superv & 42.857 & 0 & 49.635 & 0 & 0 & 1 & 1 & 168 \\
Audit & 12.500 & 0 & 33.171 & 0 & 0 & 1 & 1 & 168 \\
NPL & 0.996 & 0.955 & 34.344 & 0.380 & 74.750 & 118.00 & 2.390 & 120 \\
ALR & 2.566 & 2.500 & 0.580 & 1.440 & 2.240 & 2.683 & 4.530 & 92 \\
CAP & 12.366 & 12.185 & 1.385 & 9.880 & 11.278 & 13.170 & 16.200 & 120 \\
ROE & 16.121 & 16.420 & 3.716 & 5.940 & 13.975 & 18.580 & 24.280 & 156 \\
\hline
\end{tabular}

\subsubsection{Regression Results}

Panel A and Panel B in Table 3 show the estimation results of equations (1) and (2). The regression results indicate that Superv and Audit have significant effects on each dependent variable. This empirically verifies the significant influence of "Document No. 107" and national audit on shadow banking. Either Superv or Audit, its regression coefficient with Credit is positive, while the regression coefficient with Shadow is negative. This shows that after controlling other factors, strengthening the administrative supervision and national audit can urge banks to pay more attention to the allocation of credit assets and limit shadow banking activities. Specifically, the regression coefficients of H-Risk in Panel A and Panel B are negative, while the regression coefficients of L-Risk are positive, indicating that the implementation of "Document No.107 " and national audit have prompted commercial banks to reduce the proportion of high-risk shadow banking activities and increase the proportion of low-risk activities to control their own risks. This preliminarily confirms hypothesis H1 to H5. The absolute value of each coefficient in Panel B is greater than those in Panel A. This can be preliminary deduced that national audit has a much better mechanism than "Document No.107" in the shadow banking risk management.

Table 3. Results of panel model regression

\begin{tabular}{ccccccccc}
\hline & \multicolumn{3}{c}{ Panel A: Estimated results of equation (1) } & \multicolumn{3}{c}{ Panel B: Estimated Results of Equation (2) } \\
\hline \multirow{3}{*}{ Superv } & Credit & Shadow & H-Risk & L-Risk & Credit & Shadow & H-Risk & L-Risk \\
& $1.324^{* * *}$ & $-0.368^{* * *}$ & $-0.689^{* * *}$ & $0.386^{*}$ & & & & \\
\multirow{2}{*}{ Audit } & $(3.256)$ & $(-1.352)$ & $(-1.283)$ & $(0.674)$ & & & & \\
& & & & & $2.563^{* * *}$ & $-1.324^{* *}$ & $-1.378^{*}$ & $0.394^{*}$ \\
& & & & & $(2.357)$ & $(-1.056)$ & $(-0.954)$ & $(0.987)$ \\
NPL & $-1.657^{*}$ & $0.368^{* * *}$ & $1.286^{* * *}$ & -1.262 & $-1.002^{* * *}$ & $0.458^{* * *}$ & $-1.398^{* * *}$ & $-1.659^{* * *}$ \\
& $(-0.354)$ & $(2.278)$ & $(4.387)$ & $(-0.786)$ & $(-3.278)$ & $(1.003)$ & $(-6.785)$ & $(-7.678)$ \\
ALR & $0.453^{*}$ & -1.346 & $-1.219^{* * *}$ & 0.338 & $0.339^{* * *}$ & $-0.539^{* * *}$ & $-0.785^{* * *}$ & $0.674^{* * *}$ \\
& $(0.432)$ & $(-0.278)$ & $(-3.217)$ & $(0.675)$ & $(2.128)$ & $(-3.280)$ & $(-6.326)$ & $(1.368)$ \\
CAP & 0.338 & $-1.025^{* * *}$ & -2.212 & $0.369^{* * *}$ & $0.397^{* *}$ & $-0.683^{* * *}$ & $0.563^{* *}$ & $1.238^{* *}$ \\
& $(0.352)$ & $(-2.357)$ & $(-0.368)$ & $(8.238)$ & $(1.228)$ & $(-5.033)$ & $(1.326)$ & $(0.785)$ \\
ROE & $1.548^{* * *}$ & $-0.583^{* *}$ & $-1.368^{* * *}$ & 1.113 & $0.026^{* * *}$ & $-1.324^{* * *}$ & $-0.870^{* * *}$ & $0.563^{*}$ \\
& $(2.357)$ & $(-1.358)$ & $(-3.651)$ & $(0.768)$ & $(1.229)$ & $(-5.278)$ & $(-3.437)$ & $(0.895)$ \\
$R^{2}$ & 0.879 & 0.785 & 0.868 & 0.760 & 0.674 & 0.690 & 0.896 & 0.705 \\
\hline
\end{tabular}

Note. ***, **, and * indicate that the data is significant (two-tailed) at $0.01,0.05$, and 0.1 levels, respectively. The values in brackets in Panel A and Panel B represent the t-values of the two-tailed test. 


\subsection{DID Model Based on PSM}

\subsubsection{Reliability Test of PSM}

There may be certain differences among sample banks, and these differences can have an impact on the conclusion of this study. In order to control possible endogenous effects, this paper adopts the PSM method to conduct a robustness test on administrative supervision and national audit to better identify the net effects of their influences on shadow banking risk preference. First, according to NPL, ALR, CAP, ROE, the propensity score of each observed data can be obtained through logistic regression. By matching the sample banks in the experimental group using the nearest neighbor matching method, the experimental group based on national audit PSM can be obtained. The experimental group based on administrative supervision can be determined in the same way. Table 4 shows that according to PSM, the absolute value of the standard deviation of each matching variable is much less than 10 . Therefore, it can be inferred that the choice of matching variables and matching methods in this paper is appropriate and the PSM match is reliable (Note 4).

Table 4. PSM effect

\begin{tabular}{|c|c|c|c|c|c|c|}
\hline \multirow{3}{*}{ Control variables } & \multicolumn{3}{|c|}{ PSM Effect Based on Document No. 107} & \multicolumn{3}{|c|}{ PSM Effect Based on National Audit } \\
\hline & \multicolumn{2}{|c|}{ Mean } & \multirow{2}{*}{$\begin{array}{l}\text { standard } \\
\text { deviation }\end{array}$} & \multicolumn{2}{|c|}{ Mean } & \multirow{2}{*}{$\begin{array}{l}\text { standard } \\
\text { deviation }\end{array}$} \\
\hline & treated group & experimental group & & treated group & experimental group & \\
\hline NPL & 1.165 & 0.927 & 0.168 & 1.386 & 0.865 & 0.368 \\
\hline ALR & 2.658 & 2.509 & 0.105 & 2.569 & 1.326 & 0.879 \\
\hline CAP & 12.985 & 12.121 & 0.611 & 12.128 & 12. 879 & 0.531 \\
\hline ROE & 16.866 & 16.041 & 0.583 & 16.242 & 16.695 & 0.320 \\
\hline
\end{tabular}

\subsubsection{DID Test Based on PSM}

Based on the above PSM samples, a DID panel test is performed on equation (3) and (4) using fixed effect model. The test results are shown in Table 5 and Table 6. From column (1) and column (6), it can be inferred that, after controlling other factors, the coefficients of Treated *Exper are significantly negative, indicating that administrative supervision and national audit can significantly improve shadow banking risk structure, which is conducive to reduce the risk exposure of shadow banking. However, the significance level of Treated *Exper of formula (4) is $1 \%$, and the coefficient is -2.583 which is better than that in formula (3). From the perspective of control power, the coefficient of the experimental group of national audit shown in Table 6 is -6.657 , the absolute value of which is larger than that of "Document No.107" shown in Table 5, which is -3.548. It means that due to the authoritativeness, independence and comprehensiveness of national audit, its control over shadow banking risks is stronger than that of administrative supervision. It also plays a more important role in monitoring high-risk business and correcting the risk preferences of commercial banks. Table 5 and 6 also demonstrate the multiple effects of each variable on shadow banking structure.

First, Credit in column (2) and (7) show that both administrative supervision and national audit have significant positive impacts on the scale of bank's credit operations. These two approaches of supervision can effectively enhance the risk awareness of commercial banks, reduce shadow banking activities, and increase the proportion of credit operations. H1 has been verified. Relevant control variables indicate that NPL, CAP and ROE all have significant effects on the bank's credit operations. The higher the NPL is, the more credit operations the banks will reduce to control non-performing assets. However, the high CAP and ROE indicate that the bank has strong abilities to cope with non-performing assets. Therefore, under the motivation of pursuing higher profits, banks naturally have the enthusiasm to expand credit operations.

Secondly, from column (3) and (8), after controlling other factors, the impact of administrative supervision and national audit on shadow banking is significant, and the coefficients are all negative, which indicates that administrative supervision and national audit have significant restrictions on shadow banking and have crucial importance to safeguard the security of financial system. $\mathrm{H} 2$ and $\mathrm{H} 3$ have been verified. Variables CAP and ROE show that strengthening capital regulations and improving the CAP and ROE of commercial banks will be beneficial to "crowd out" shadow banking activities, thereby reducing the risks of commercial banks. 
Table 5. DID panel test results of equation (3)

\begin{tabular}{|c|c|c|c|c|c|}
\hline Dependent variable & Struc (1) & Credit (2) & Shadow (3) & H-Risk (4) & L-Risk (5) \\
\hline \multirow{2}{*}{ Treated } & $-2.548^{*}$ & $1.352 * *$ & $-1.685^{*}$ & $-0.769^{*}$ & $1.216^{*}$ \\
\hline & $(-0.665)$ & (1.153) & $(-0.890)$ & $(-0.806)$ & $(0.984)$ \\
\hline \multirow{2}{*}{ Exper } & $-3.548^{* * *}$ & $2.314^{* *}$ & $-1.125^{*}$ & $-1.897^{* *}$ & $2.219^{* * *}$ \\
\hline & $(-4.687)$ & (1.547) & $(-0.980)$ & $(-1.237)$ & $(2.958)$ \\
\hline \multirow{2}{*}{ Treated $*$ Exper } & $-1.437^{*}$ & $0.326^{*}$ & $-0.153^{*}$ & $-1.236^{*}$ & $0.335^{*}$ \\
\hline & $(-0.835)$ & $(0.658)$ & $(-0.658)$ & $(-0.863)$ & $(0.986)$ \\
\hline \multirow{2}{*}{ NPL } & $-1.214^{* *}$ & $-1.785^{* *}$ & $2.769^{* * *}$ & $0.363^{*}$ & 0.126 \\
\hline & $(-1.563)$ & $(-1.821)$ & (3.563) & $(0.987)$ & $(0.068)$ \\
\hline \multirow{2}{*}{ ALR } & -0.764 & 1.327 & 1.658 & 0.698 & 0.328 \\
\hline & $(-0.097)$ & $(0.065)$ & $(0.157)$ & $(0.232)$ & $(0.219)$ \\
\hline \multirow{2}{*}{ CAP } & 1.347 & $0.672^{*}$ & $-1.259^{* *}$ & $-1.569^{* *}$ & $0.351^{*}$ \\
\hline & $(0.036)$ & $(0.986)$ & $(-1.136)$ & $(-1.875)$ & $(0.832)$ \\
\hline \multirow{2}{*}{ ROE } & $0.549^{* *}$ & $1.217^{* *}$ & $-1.119^{* * *}$ & $-0.984^{* *}$ & $0.375^{*}$ \\
\hline & $(1.547)$ & $(1.896)$ & $(-1.327)$ & $(-1.563)$ & $(0.784)$ \\
\hline Adjusted $\mathrm{R}^{2}$ & 0.619 & 0.782 & 0.685 & 0.769 & 0.751 \\
\hline
\end{tabular}

Note. The value in parentheses is the $\mathrm{t}$ value of two-tailed test. *,**, and *** indicate that the data is significant at $0.1,0.05$, and 0.01 levels, respectively.

Finally, from the perspective of shadow banking structure, column (4) and (9) show that after controlling other factors, administrative supervision and national audit have significant impacts on high-risk shadow banking activities. They both have significantly reduced the proportion of high-risk shadow banking activities. $\mathrm{H} 4$ and H5 have been verified. The coefficient of administrative supervision at the 5\% significance level is -1.897 , while the coefficient of national audit at the $1 \%$ significance level is -3.458 . This shows that in monitoring high-risk activities, national audit can detect and resolve the risks of shadow banking more efficiently due to its comprehensiveness and diversity. In conclusion, compared to administrative supervision, national audit has stronger regulations on shadow banking risks.

Table 6. DID panel test results of equation (4)

\begin{tabular}{|c|c|c|c|c|c|}
\hline Dependent variable & Struc (6) & Credit (7) & Shadow (8) & H-Risk (9) & L-Risk (10) \\
\hline \multirow{2}{*}{ Treated } & $-1.547^{* * *}$ & $1.895^{* *}$ & $-0.769^{*}$ & $-0.638^{*}$ & $1.870^{* *}$ \\
\hline & $(-2.326)$ & (1.786) & $(-0.983)$ & $(-0.985)$ & (1.563) \\
\hline \multirow{2}{*}{ Exper } & $-6.657^{* * *}$ & $2.314^{* *}$ & $-3.093^{* *}$ & $-3.458^{* * *}$ & $2.785^{* * *}$ \\
\hline & $(-12.326)$ & $(6.768)$ & $(-1.365)$ & $(-3.761)$ & $(3.438)$ \\
\hline \multirow{2}{*}{ Treated $*$ Exper } & $-2.583^{* * * *}$ & $0.564^{*}$ & $-1.096^{* *}$ & $-0.659^{* *}$ & $0.975^{*}$ \\
\hline & $(-7.835)$ & $(0.356)$ & $(-1.132)$ & $(-1.327)$ & $(0.997)$ \\
\hline \multirow{2}{*}{ NPL } & $-1.548^{* * *}$ & $-2.125^{* *}$ & $0.674^{*}$ & $1.117^{*}$ & 0.874 \\
\hline & $(-2.327)$ & $(-1.769)$ & $(0.985)$ & $(0.879)$ & $(0.239)$ \\
\hline \multirow{2}{*}{ ALR } & $-1.386^{* *}$ & $-0.154^{*}$ & 1.217 & 1.327 & 1.354 \\
\hline & $(-1.874)$ & $(-0.968)$ & $(0.021)$ & $(0.452)$ & $(0.563)$ \\
\hline \multirow{2}{*}{ CAP } & $5.659^{* * *}$ & $0.437^{*}$ & $-2.125^{* * *}$ & $-2.450^{* *}$ & $0.997^{*}$ \\
\hline & $(7.768)$ & $(0.869)$ & $(-5.361)$ & $(-1.673)$ & $(0.908)$ \\
\hline \multirow{2}{*}{ ROE } & $2.540^{* * *}$ & $1.896^{* *}$ & $-1.548^{*}$ & $-1.113^{* * *}$ & $1.908^{*}$ \\
\hline & $(6.453)$ & $(1.768)$ & $(-0.879)$ & $(-2.574)$ & $(0.986)$ \\
\hline Adjusted $\mathrm{R}^{2}$ & 0.695 & 0.769 & 0.658 & 0.614 & 0.729 \\
\hline
\end{tabular}

Note. The value in parentheses is the $\mathrm{t}$ value of two-tailed test. *, **, and *** indicate that the data is significant at $0.1,0.05$, and 0.01 levels, respectively.

\section{Conclusions and Policy Implications}

Based on the panel data model and PSM-DID model, this paper evaluates and compares the impacts of "Document No.107" and national audit on shadow banking risk preference. The results show that "Document No.107" and national audit can control China's shadow banking risks effectively, improve the risk structure, and reduce the risk preference of shadow banking effectively, which ensure the security of China's financial system. 
However, since administrative supervision and national audit have different supervisory means and operational mechanisms, it will inevitably require the collaboration and complementarity between them to regulate shadow banking in the future. This provides direct empirical evidence for the regulatory authorities to improve the robustness of financial system and to prevent systemic regional financial risks, and it has strong policy implications.

Firstly. Strengthen the risk supervision of shadow banking of all countries. The huge scale and rapid growth of shadow banking imply higher and higher risks. The prevention and resolution of shadow banking risks are important for the stability and security of macroeconomy. In order to prevent shadow banking risks effectively, "Document No. 107" explicitly is proposed to establish a financial supervision mechanism and urge relevant institutions to build internal control system, risk disposal system, and risk isolation mechanisms. Particularly in China, under the background of new normal economy, financial institutions have all experienced "asset shortage" during the process of economic growth from high speed to medium-high speed. During the economic recession, the deterioration in the quality of credit assets has not yet been effectively controlled, and the exposure of credit risks of non-standard assets has become more and more serious. Compared with assets on the balance sheet, shadow banking which is less-regulated or even unregulated has greater risks of deterioration. Therefore, it is necessary to adopt diversified and comprehensive regulatory measures to urge commercial banks to further regulate nesting in order to effectively prevent and control shadow banking risks.

Secondly. Make the most of national audit in the risk supervision framework of shadow banking and form a regulatory synergy. Judging from the basic reality of China's economy, the exposure of shadow banking risks has increased under the pressure of economic downturn and the accelerating release of financial risks. Although China has promulgated many laws and regulations on shadow banking risk supervision, the risk preference of financial institutions has not fundamentally changed. One of the most important reasons is the regulatory gap and gray zone formed by separate supervision, which makes a lot of shadow banking activities stay out of government regulation. At the National Auditing Conference in 2018, the Chinese Auditor General pointed out that it is necessary to take advantage of the expertise, extensive range, and rapid response of national audit to deeply reveal the hidden risks of shadow banking. Therefore, considering the professionalism, comprehensiveness, and authoritativeness of national audit, it is important to collaborate between national audit and administrative supervision, embed the national audit mechanism into the traditional financial regulatory framework, and strengthen the penetrating and crossing supervision. The "immune system" of national audit can better correct and constrain the cross financial risks of shadow banking to prevent systematic financial risks.

Thirdly. Actively guide the financial resources into real economy and reinforce the foundation for high-quality economic development. To establishing a sound financial supervision system and prevent systematic financial risks is the fundamental requirement and guideline of all countries in the financial field. However, there are multiple contradictions in the economic development around the world, especially the problem of financial resources transferring from real economy into fictitious economy, and the problem of cash idling and deindustrialization. The effective implementation of administrative supervision and national audit can effectively restrain the risks of shadow banking, help banks increase the total amount of credit assets to the real economy, and even improve the CAP, ROE and the quality of financial assets. Therefore, it is necessary to strengthen the political guidance and cooperation of administrative supervision and national audit and make the most of their advantages, so that the risks of shadow banking can be controlled. This is conducive to help financial institutions correct their risk preferences and constrain shadow banking activities. In this way can we fundamentally improve the efficiency of supervision and prevent financial risks, creating a solid foundation for the high-quality development of the world economy.

\section{Acknowledgements}

This is the periodical achievement of the National Social Science Fund Project "Research on Risk Contagion and Audit Governance Mechanism of Shadow banking “ (Project Approval Number: 15BGL045), Key Project of Philosophy and Social Science of Jiangsu Universities "Research on Governance of Internet Financial Risk under the Perspective of Government Audit" (Project Approval Number: 2017ZDIXM102), Social Science Fund Project of Jiangsu Province "Research on the Mechanism of Risk Contagion and Audit Governance of Cross Financial Risk in the Point of Big Data" (Project Approval Number: 17GLD012), the Key Research Project of Nanjing Audit University Government Audit Institute "Research on Long-term Mechanism of Governance of Internet Financial Risk under Government Audit" (Project Approval Number: GASA171007) and the funding project of the Construction of Dominant Discipline of Jiangsu Universities. 


\section{References}

Adrian, A. A., \& Boesky, H. (2014). Shadow Banking. Federal Reserve Bank of New York Staff Reports, No. 458.

Bo, L., \& Ge, W. (2011). The credit creation function of shadow banking and its challenge to monetary policy. Financial Research, 12(12), 77-84.

Gennaioli, N., Shleifer, A., \& Vishny, R. (2012). Neglected Risks, Financial Innovation, and Financial Fragility. Journal of Financial Economics, 4(3), 452-468. https://doi.org/10.1016/j.jfineco.2011.05.005

Gertler, M., \& Kiyotaki, N. (2013). Bangking, Liquidity and Bank Runs in an Infinite-Horizon Economy. NBER Working Paper No. 19129.

Hongxing, F., \& Jiaojiao, C. (2016). Cross-subsidy between two kinds of audit fees under the integrated mode. Audit Research, 12(1), 68-75.

Huang, X. (2009). A Framework for Assessing the Systemic Risk of Major Financial Institutions. Journal of Banking and Financ, 33(20), 2036-2049. https://doi.org/10.1016/j.jbankfin.2009.05.017

Jiahua, W., \& Yuanfang, C. (2017). Butterfly Effect and Audit Governance Mechanism of Shadow Banking Risks. Economic Issues, 12(1), 67-72.

Jing, H. (2016). Does delayed executive compensation reduce bank's risk preference?. Finance and Trade Economics, 12(11), 77-95.

Lehar, A. (2005). Measuring Systemic Risk: A Risk Management Approach. Journal of Banking and Finance, 29(10), 2577-2603. https://doi.org/10.1016/j.jbankfin.2004.09.007

Liu, X., Yi, H., \& Ye, T. (2014). Comparative Study on China's Monetary Policy Rules under Dual Structure of Shadow Banking and Formal Finance. Journal of Finance and Economics, 29(1), 15-26.

Minkang, L., \& Zheng, L. (2015). Media Attitude, Investor Concern, and Audit Opinions. Audit Research, 12(3), 64-72.

Nicolo, G., \& Kwast, M. (2002). Systemic Risk and Financial Consolidation: Are They Related? Journal of Banking and Finance, 26(5), 861-880. https://doi.org/10.1016/S0378-4266(02)00211-X

Pozsar. (2013). Institution Cash Pools and the Triffin Dilemma of the US Banking System. Financial Mmarkets, Institution \& Instrument, 12(2), 283-318. https://doi.org/10.1111/fmii.12013

Rui, H., \& Hai, J. (2013). Implementation of Capital Requirements of Basel III and Bank's countermeasures Research: Based on Numerical Simulation of DSGE Model. Journal of Finance and Economics, 28(6), 116-126.

Ryoo, S. (2010). Long Waves and Short Cycles in a Model of Endogenous Financial Fragility. Journal of Economic Behavior and Organization, 74(3), 163-186. https://doi.org/10.1016/j.jebo.2010.03.015

Susong, B. (2013). Objective assessment of shadow banking from the perspective of financial structure evolution. Economic Review, 12(4), 10-36.

Zhou, L. (2013). Shadow Banking System: The Return of Free Banking? Beijing: Social Sciences Academic Press.

\section{Notes}

Note 1. The "Decision of the Central Committee of the Communist Party of China on Several Major Issues Concerning Ruling the Country in Accordance with Law" reviewed and adopted at the Fourth Plenary Session of the 18th CPC Central Committee puts forward the goals and requirements that "Efforts should be made to strengthen the supervision within the Party, supervision of People's Congress, democratic supervision, administrative supervision, judicial supervision, audit supervision, social supervision, and public opinion supervision, to form a scientific and effective system of power control and regulation, and to strengthen the cooperation and effectiveness of supervision." The decision also clearly defines the eight components that constitute the power operation control and supervision system. At this point, national audit became independent from administrative supervision for the first time to become one of the "eight major supervisions", marking the party and the country's new understanding and new positioning of the state's audit function.

Note 2. The outbreak of liquidity crisis in China's banking industry at the end of the second quarter of 2013 is a typical example. 
Note 3. That's because the audit notice of National Audit Office on central enterprises mainly started in 2010.

Note 4. Rosenbaum and Rubin (1985) pointed out that the threshold standard deviation of PSM effect is 20, and the absolute value of the standard deviation within 20 is acceptable.

\section{Copyrights}

Copyright for this article is retained by the author(s), with first publication rights granted to the journal.

This is an open-access article distributed under the terms and conditions of the Creative Commons Attribution license (http://creativecommons.org/licenses/by/4.0/). 